\title{
KNN Dan Gabor Filter Serta Wiener Filter Untuk Mendiagnosis Penyakit Pneumonia Citra X-RAY Pada Paru-Paru
}

\author{
Felix Antony ${ }^{1}$, Hafiz Irsyad ${ }^{2}$, Muhammad Ezar Al Rivan ${ }^{3}$ \\ ${ }^{1,2,3}$ STMIK GI MDP; Jalan Rajawali No. 14 Palembang, 0711-376400 \\ ${ }^{1,2,3}$ Program Studi Teknik Informatika, STMIK GI MDP, Palembang \\ e-mail: ${ }^{1}$ felixantony1999@gmail.com, ${ }^{2}$ hafizirsyad@mdp.ac.id, ${ }^{3}$ meedzhar@mdp.ac.id
}

\begin{abstract}
Abstrak
Pneumonia adalah salah satu jenis penyakit paru-paru yang disebabkan oleh bakteri, virus, jamur, ataupun parasit. Salah satu cara untuk mengetahui penyakit pneumonia adalah dengan rontgen atau $x$-ray. Hasil rontgen akan dianalisis untuk mengetahui apakah terdapat pneumonia atau tidak. Penelitian ini bertujuan untuk mengklasifikasi hasil rontgen apakah terdapat pneumonia atau tidak pada hasil rontgen. metode yang digunakan untuk klasifikasi adalah K-Nearest Neighbor (KNN) dan metode ekstraksi Gabor Filter serta Wiener Filter. Tahapan yang dilaukan pada citra sebelum di Klasifikasi yaitu Resize, selanjutnya dilakukan ekstraksi menggunakan Gabor Filter, Image Enhancement menggunakan Wiener Filter dan di klasifikasi menggunakan K-Nearest Neighbor (KNN) menghasilkan akurasi terbaik sebesar $79,62 \%$.
\end{abstract}

Kata kunci : K-Nearest Neighbor, Gabor Filter, Wiener Filter, Paru-paru, Pneumonia

\begin{abstract}
Pneumonia is a type of lung disease caused by bacteria, viruses, fungi, or parasites. One way to find out pneumonia is by X-ray or $x$-ray. X-ray results will be analyzed to find out whether there is pneumonia or not. This study aims to classify the $x$-ray results whether there is pneumonia or not on the $x$-ray results. The method used for the classification of K-Nearest Neighbor (KNN), the Gabor Filter extraction method and Wiener Filter for Image Enhancement. Stages carried out in the image before the classification are resize, then extraction using Gabor Filter, image enhancement using Wiener Filter and in classification using K-Nearest Neighbor (KNN) produces the best accuracy of 79,62\%
\end{abstract}

Keywords : K-Nearest Neighbor, Gabor Filter, Wiener Filter, Lungs, Pneumonia

\section{PENDAHULUAN}

$P$ aru-paru [1] [2] merupakan organ pernafasan yang berhubungan dengan sistem pernafasan dan sirkulasi darah dalam tubuh mahkluk hidup yang bernafas dengan udara. Fungsi utama paru-paru adalah melepaskan karbondioksida dari peredaran darah ke udara. Dalam proses pernapasan, udara memasuki mulut atau hidung, dan melewati trakea (tenggorokan), bronkus, bronkiolus serta alveoli. Aveoli menyebarkan oksigen ke seluruh tubuh, sedangkan karbondioksida dikeluarkan dari seluruh tubuh.

Pneumonia (paru-paru basah) [3] adalah kondisi dimana seseorang mengalami infeksi yang terjadi pada kantung-kantung udara dalam paru-paru orang tersebut. Infeksi yang ditimbulkan pneumonia bisa terjadi pada salah satu sisi paru-paru maupun keduanya. Katung udara yang 
terinfeksi tersebut akan terisi oleh cairan. Infeksi virus, bakteri maupun jamur adalah penyebab utama pneumonia.

SARS-CoV-2 yang menyebabkan COVID-19 adalah salah satu jenis virus yang bisa menyebabkan pneumonia. Pneumonia akibat COVID-19 bisa menyebabkan komplikasi berbahaya, salah satunya adalah acute respiratory distress syndrome (ARDS). Pneumonia merupakan salah satu penyebab kematian tertinggi pada anak-anak di seluruh dunia. Badan Kesehatan Dunia (WHO) memperkirakan bahwa 15\% kematian anak-anak berusia dibawah 5 tahun disebabkan oleh penyakit ini. WHO juga menyatakan bahwa pada tahun 2017, terdapat lebih dari 800.000 anak meninggal akibat pneumonia.

Penelitian mengenai pneumonia pernah dilakukan sebelumnya, seperti yang dilakukan oleh Nu'man, Sri Kusumadewi, Nurlaili Muzayyanah pada tahun 2020 [4] membahas mengenai Sistem Inferensi Fuzzy Untuk Membantu Diagnosis Penyakit Pneumonia Anak dengan menggunakan metode Fuzzy Tsukamoto yang bertujuan untuk mendiagnosis pneumonia dengan klasifikasi yang benar berdasarkan gejala yang diderita pasien dengan akurasi sebesar $80 \%$, sensitifitas sebesar $75 \%$, dan spesitifitas sebesar $83 \%$. Setelah mengetahui diagnosis yang didapat, maka perlakuan yang tepat dapat memberikan dan tingkat kesalahan dalam mendiagnosis anak-anak dapat diminimalisir. Hasil dari pengujian terhadap 10 data uji memberikan rekomendasi diagnosis 8 dari 10 data yang sesuai dengan hasil rekam medis.

Penelitian mengenai pneumonia juga pernah dilakukan oleh I Md. Dendi Maysanjaya [5] pada tahun 2020 membahas mengenai Klasifikasi Pneumonia pada Citra X-rays Paru-paru dengan Convolutional Neural Network (CNN) yang bertujuan menguji kinerja CNN dalam menangani dataset baru yang diperoleh dari platform Kaggle sejumlah 5.840 citra, yang terdiri atas 1.575 citra paru-paru normal dan 4.265 citra paru-paru pneumonia. Data dibagi menjadi data latih dan data uji, dengan jumlah data secara berurutan 5.216 citra dan 624 citra dengan hasil yang diperoleh nilai gap pada loss data sebesar $47.43 \%$. dan rata-rata nilai akurasi $89.5 \%$.

Penelitian mengenai pneumonia juga pernah dilakukan oleh Beny My Sapata, Dwi Juniati pada tahun 2019 [6] membahas mengenai klasifikasi penyakit paru berdasarkan citra $x$-ray thorax menggunakan metode fractal box counting yang bertujuan mendiagnosis hasil citra $x$-ray dengan hasil dari akurasi terbesar $79.65 \%$ pada nilai $K=5$, dan akurasi terendah $71.28 \%$ pada nilai $\mathrm{K}=7$.

Penelitian mengenai pneumonia juga pernah dilakukan oleh Reni Rahmadewi dan Rahmadi Kurnia pada tahun 2016 [7] membahas mengenai klasifikasi penyakit paru berdasarkan citra rontgen dengan metode segmentasi Sobel yang bertujuan menganalisis gambar rontgen berdasarkan pengolahan citra untuk mempermudah mendapatkan hasil diagnosa. Hasil pengujian yang didapat dari perbandingan piksel antara hasil deteksi tepi terhadap region paru, yang mengklasifikasikan penyakit pneumonia dengan interval presentase perbandingan jumlah piksel putih (deteksi tepi) dengan total piksel paru (segmentasi) sebesar 2,00\% - 2,50\%.

Penelitian mengenai pneumonia juga pernah dilakukan oleh Risha Ambar wati, Hafiz Irsyad, M Ezar Al Rivan (2020) [8] membahas mengenai Klasifikasi Pneumonia Menggunakan Metode Support Vector Machine yang mendapatkan hasil pengujian bahwa performa SVM dengan fitur GLCM untuk jenis citra paru-paru yang mengidap pneumonia dengan dataset testing 600 mendapatkan nilai accuracy 62,66\%, sedangkan dataset testing 750 mendapatkan nilai accuracy 59,2\% sehingga metode SVM tidak cukup baik untuk mengklasifikasi penyakit pneumonia.

Gabor Filter [9] telah digunakan dalam aplikasi pemrosesan gambar, seperti segmentasi tekstur dan deteksi tepi. Untuk mengakomodasi ruang tag lokal dan perubahan orientasi, hasil beberapa fase yang sesuai dengan yang berbeda ruang dan orientasi tag, yang digabungkan untuk membuat peta fase terakhir dengan tanggapan lokal. Gabor filter terdiri dari filter yang sesuai dengan tag yang berbeda jarak dan sudut orientasi. Besarnya keluaran filter Gabor di lokasi tertentu bervariasi untuk pengaturan parameter filter yang berbeda dimaksimalkan ketika parameter cocok dengan ruang tag lokal dan orientasi. 
Jurnal Algoritme

Pada penelitian penggunaan metode Gabor Filter pernah dilakukan sebelumnya, seperti yang dilakukan oleh Khairunnisa, Rismayanti, dan Rully Alhari pada tahun 2018 [10], membahas mengenai Analisis Identifikasi Wajah menggunakan Gabor Filter dan Skin Model yang mendapatkan hasil pengujian bahwa akurasi paling tinggi adalah $93.6349 \%$, dan akurasi paling rendah berkisar $82,45 \%$, sehingga identifikasi wajah manusia bisa dengan cepat dan akurat dengan menggunakan Gabor Filter dan Skin Model dimana informasi wajah yang telah didapat diekstraksi menggunakan Gabor Filter. Kombinasi kedua metode tersebut menghasilkan proses yang lebih cepat dimana pada ekstraksi Gabor Filter tidak semua piksel dari citra yang diproses melainkan hanya area wajah hasil seleksi Skin Color Model sehingga proses menjadi lebih cepat dibandingkan dengan memproses keseluruhan piksel dari citra.

Wiener Filter [11] dengan tujuan agar filter ini dapat menghitung estimasi optimum pada sinyal dari noisy measurement. Wiener Filter berdasarkan pencapaian stastistika dan menghasilkan Minimum Mean Square Error (MMSE). Wiener Filter memiliki karakteristik Assumption (sinyal dan noise diproses secara stokastik linear tetap dengan diketahui karakteristik atau diketahui autocorrelation and crosscorrelation), Requirement (dapat direalisasikan), Performance Requirement (berupa MMSE).

Penelitian mengenai penggunaan metode Wiener Filter pernah dilakukan sebelumnya, seperti yang dilakukan oleh Nono Heryana, dan Rini Mayasari (2016) [12] membahas mengenai Implementasi Noise Removal Menggunakan Wiener Filter untuk Perbaikan Citra Digital dengan tujuan untuk meminimalkan Mean Square Error untuk keseluruhan proses invert filter, smoothing noise dan metode Wiener Filter optimal dalam melakukan perbaikan citra, terutama citra yang memiliki Gaussian Noise, sehingga citra asal memiliki Gaussian noise Ketika diproses menggunakan metode Wiener Filter akan mengalami peningkatan kualitas citra.

Penelitian penggunaan metode Wiener Filter juga pernah dilakukan oleh Ribka Delima Sinaga (2017) [13] membahas mengenai Weiner Filter, dapat memperbaiki kualitas citra. Weiner Filter dapat meminimumkan galat restorasi. Namun, kualitas citra gambar yang dihasilkan tidak dapat dipertahankan sehingga gambar yang sudah diproses akan tampak sedikit blur.

K-Nearest Neighbor (K-NN) [14] termasuk kelompok Instance Based Learning. Algoritma ini juga merupakan salah satu teknik lazy learning. KNN dilakukan dengan mencari kelompok k objek dalam data training yang paling dekat dengan objek pada data baru atau data testing. Nilai k secara umum ditentukan dalam jumlah ganjil untuk menghindari munculnya jumlah jarak yang sama dalam pengklasifikasian. Dekat jauhnya data testing dengan data training dihitung berdasarkan jarak Euclidean. Penelitian penggunaan metode klasifikasi KNN membahas mengenai Klasifikasi pada Penyakit Dental Caries Menggunakan Gabungan $K$ Nearest Neighbor dan Algoritme Genetika [15] yang mendapatkan nilai fitness tertinggi sebesar 0,9 dengan akurasi sebesar $88 \%$ dengan nilai K optimal.

Penelitian mengenai penggunaan metode klasifikasi KNN pernah dilakukan sebelumnya, seperti yang dilakukan oleh Esi Putri Silmina, Tikaridha Hardiani pada 2018 [16] membahas mengenai Perancangan Sistem Pakar Penyakit Pneumonia Pada Balita Menggunakan algoritma K-NN (K-Nearest Neighbor) yang bertujuan untuk mendiagnosis penyakit Pneumonia pada balita, dengan 2 jenis hasil diagnosis yaitu Pneumonia ringan dan Pneumonia berat. Hasil dari pengujian terhadap 22 data training terdapat $81 \%$ nilai similarity terbesar.

Penelitian mengenai pneumonia dan penggunaan metode klasifikasi KNN pernah dilakukan sebelumnya oleh Chandra Wijaya, Hafiz Isyard, dan Wijang Widhiarso pada 2020 [17] membahas mengenai Klasifikasi Pneumonia Menggunakan Metode K-Nearest Neighbor dengan Ekstraksi GLCM yang bertujuan untuk mengklasifikasikan hasil rontgen apakah ada pneumonia secara cepat dan tepat melalui suatu program. Hasil dari penelitian menunjukkan bahwa akurasi terbaik per kelas adalah $66,20 \%$ untuk $\mathrm{K}=5$.

Antony, et., al (KNN dan Gabor Filter Serta Wiener Filter untuk Mendiagnosis Penyakit Pneumonia Citra X-Ray pada Paru-paru) 


\section{METODE PENELITIAN}

Jalannya proses penelitian ini mengikuti langkah-langkah yang tersaji pada Gambar 1 .

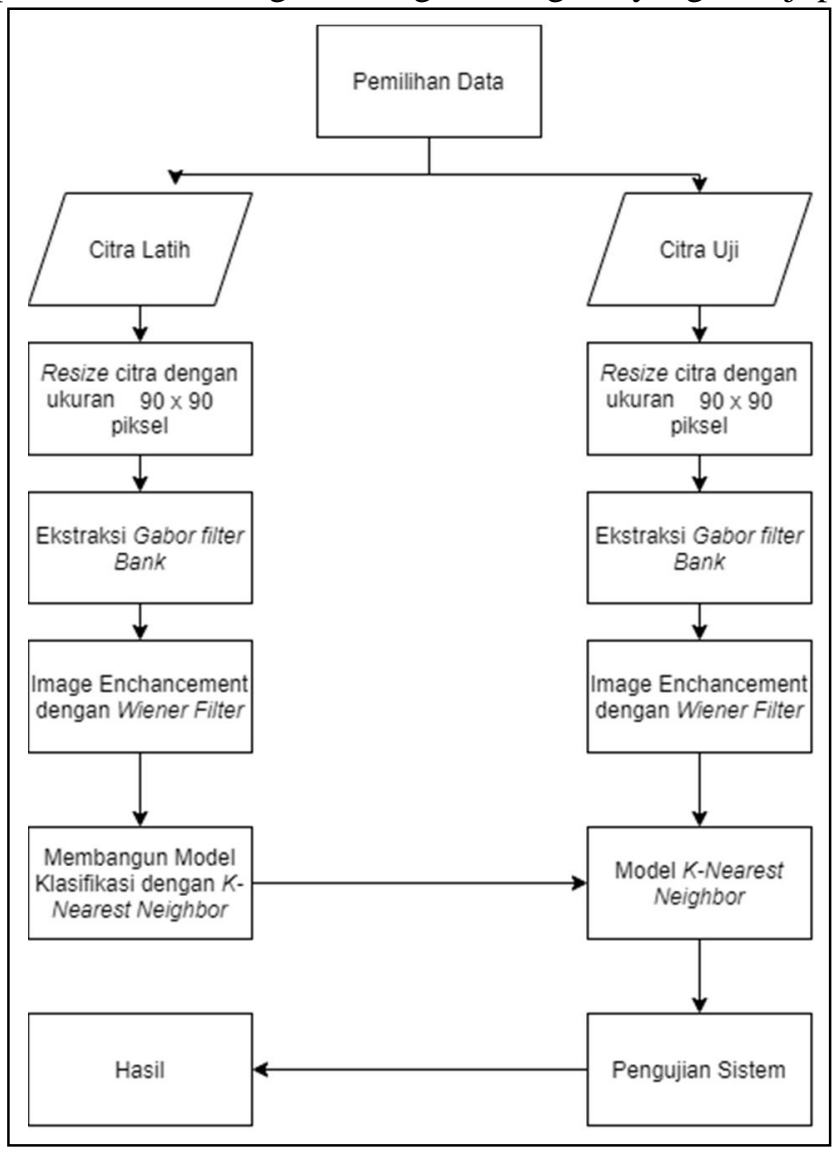

Gambar 1. Metodologi Penelitian

\subsection{Identifikasi Masalah}

Pada tahap ini yaitu melakukan pengumpulan informasi berupa jurnal terbaru dan teori tentang klasifikasi Pneumonia, metode ekstraksi menggunakan Gabor Filter, dan metode klasifikasi menggunakan $K$-Nearest Neighbor yang digunakan peneliti sebagai referensi dan apa yang harus dilakukan untuk memecahkan masalah.

\subsection{Studi Literatur}

Pada tahap ini dilakukan pembelajaran mengenai topik masalah penelitian berdasarkan jurnal terbaru dan teori tentang klasifikasi Pneumonia, metode ekstraksi menggunakan Gabor Filter, dan metode klasifikasi menggunakan K-Nearest Neighbor.

\subsection{Pengambilan Data}

Pada tahap ini, dilakukan pengambilan data. Data yang diambil adalah gambar sinar $x$-ray pada paru-paru yang terkena dan tidak terkena pneumonia yang ada di 'Chest X Ray (Pneumonia)' yang berada pada website Kaggle.

\subsection{Ekstraksi Ciri dengan Gabor Filter}

Pada tahap ini dilakukan ekstraksi fitur dengan Gabor Filter untuk mendapat sinyal gambar pada data yang akan diuji dan dilatih. Hasil dari ekstraksi ciri ini akan diolah kembali dengan menggunakan metode image enhancement Wiener Filter. 


\subsection{Image Enhancement dengan Wiener Filter}

Pada tahap ini dilakukan image enhancement dengan Wiener Filter untuk mendapat restorasi citra pada data yang akan diuji dan dilatih. Hasil dari restorasi ciri ini akan digunakan untuk tahap selanjutnya pada pembagunan model model latih dengan menggunakan metode $K$ Nearest Neighbor.

\subsection{Perancangan Sistem}

Pada tahap ini, dilakukan pembentukan dataset penelitian. Untuk pembagian dataset penelitian dapat dilihat pada Gambar 2.

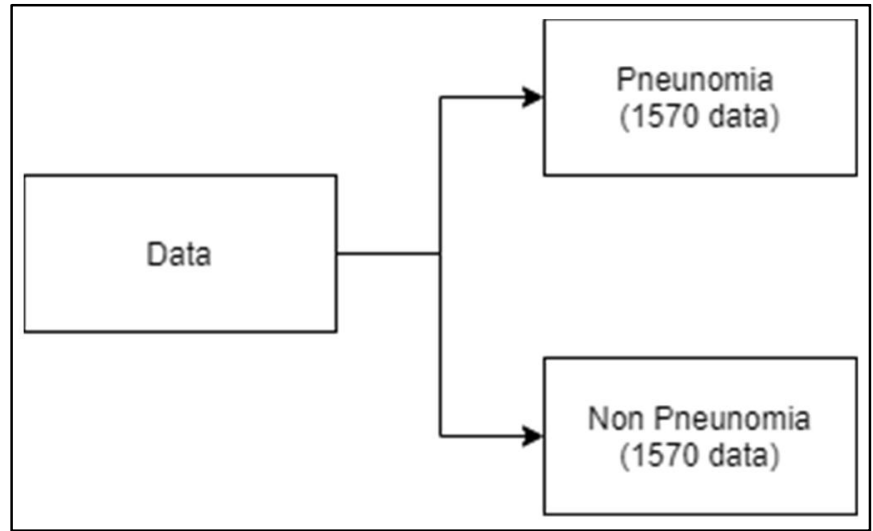

Gambar 2. Pembagian Data

Keseluruhan dataset pneumonia yang dipakai adalah 5.863 data yang terdiri dari gambar yang terkena pneumonia dan data yang tidak terkena pneumonia. Namun, data yang akan digunakan dalam pengujian hanya dipilih sebanyak 3.140 secara acak dimana data yang terdiri dari 1.570 citra pneumonia dan 1.570 cira non-pneumonia. Setelah data dipilih, data dibagi menjadi $90 \%$ untuk data latih (masing-masing kelas terdiri dari 1.413 data latih) dan $10 \%$ untuk data uji (masing-masing kelas terdiri dari 157 data uji yang digunakan untuk pengujian model dan pengujian, data citra yang telah dibagi akan dilakukan tahap resize dengan ukuran citra 90x90.

\section{Resize Citra Ukuran $90 \times 90$}

Pada tahapan ini dilakukan resize citra dengan ukuran 90x90 piksel. Foto yang telah diubah akan digunakan pada tahapan selanjutnya.

\section{Ekstraksi Gabor Filter}

Pada tahapan selanjutnya, gambar yang telah diresize, akan digunakan untuk ekstraksi menggunakan Gabor Filter. Parameter frequency yang digunakan adalah 0.1, 0.2, 0.3, 0.4, $0.5,0.6,0.7,0.8,0.9,1.0$

\section{Image Enhancement dengan Wiener Filter}

Pada tahapan selanjutnya gambar yang telah di ekstraksi, akan dilakukan image enchancement dengan menggunakan Wiener Filter. Parameter noise yang digunakan dalam Wiener Filter adalah 100, 200, 300.

4. Membangun Model dengan K-Nearest Neighbor Pada Tahapan ini, hasil dari data uji setelah tahapan wiener akan digunakan membangun model KNN yang digunakan pada tahapan selanjutnya dengan $K=1, K=3$, dan $K=5$. 


\subsection{Pengujian Sistem}

Pengujian dilakukan dengan model yang telah dibangun dengan tahapan seperti yang diberikan pada Gambar 3 dimana Hasil berupa prediksi kelas data yang dimasukan.

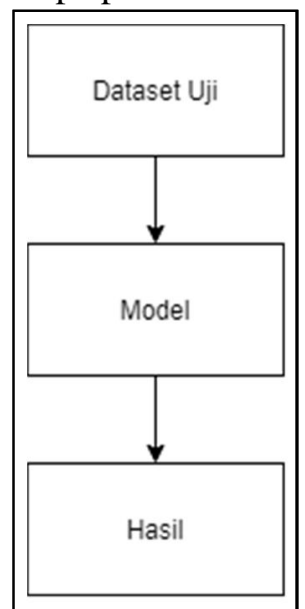

\section{Gambar 3. Pengujian Sistem}

\subsection{Evaluasi}

Pada tahapan evaluasi, akan dilakukan pengujian sebanyak 1 kali berdasarkan parameter pada Gabor Filter adalah 0.1,0.2,0.3,0.4,0.5,0.6,0.7,0.8,0.9, dan 1.0dengan parameter Wiener Filter adalah 100, 200, 300 dan nilai dari k pada K-Nearest Neighbor adalah 1, 3, dan 5 .

\section{HASIL DAN PEMBAHASAN}

Pembahasan terhadap hasil penelitian dan pengujian mengenai hasil yang didapatkan dari setiap kesimpulan pada $K$-Nearest Neighbor pada pneumonia untuk $\mathrm{K}=1, \mathrm{~K}=3, \mathrm{~K}=5$ pada gambar 4. Dan berdasarkan pada normal untuk $\mathrm{K}=1, \mathrm{~K}=3, \mathrm{~K}=5$ pada gambar 5 .

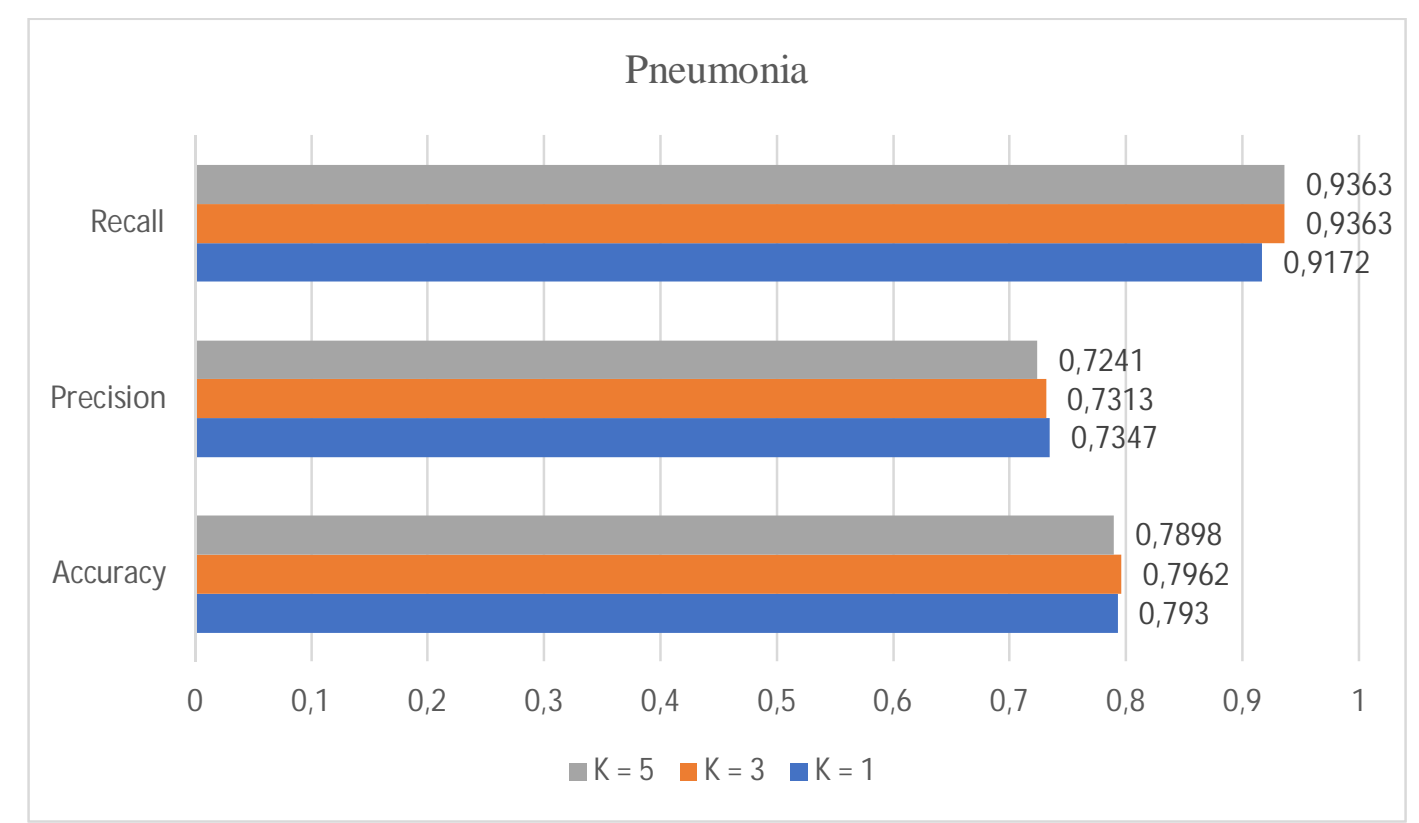

Gambar 4. Grafik Pneumonia berdasarkan $K=1, K=3$, dan $K=5$ 
Dari Gambar 4 bisa disimpulkan bahwa dari 3 parameter K untuk tingkat akurasi pada kelas pneumonia yang terbesar adalah K-Nearest Neighbor dengan parameter K = 3, Gabor Filter dengan frequency sebesar 0.5, dan Wiener Filter dengan noise 100, 200, dan 300 sebesar $79,62 \%$, tingkat Presisi sebesar 73,13\%, dan tingkat recall sebesar 93,63\%. Pada kelas pneumonia terdapat tingkat presisi yang agak kurang baik dikarenakan adanya sebagian data kelas pneumonia dikasifikasi menjadi kelas normal.

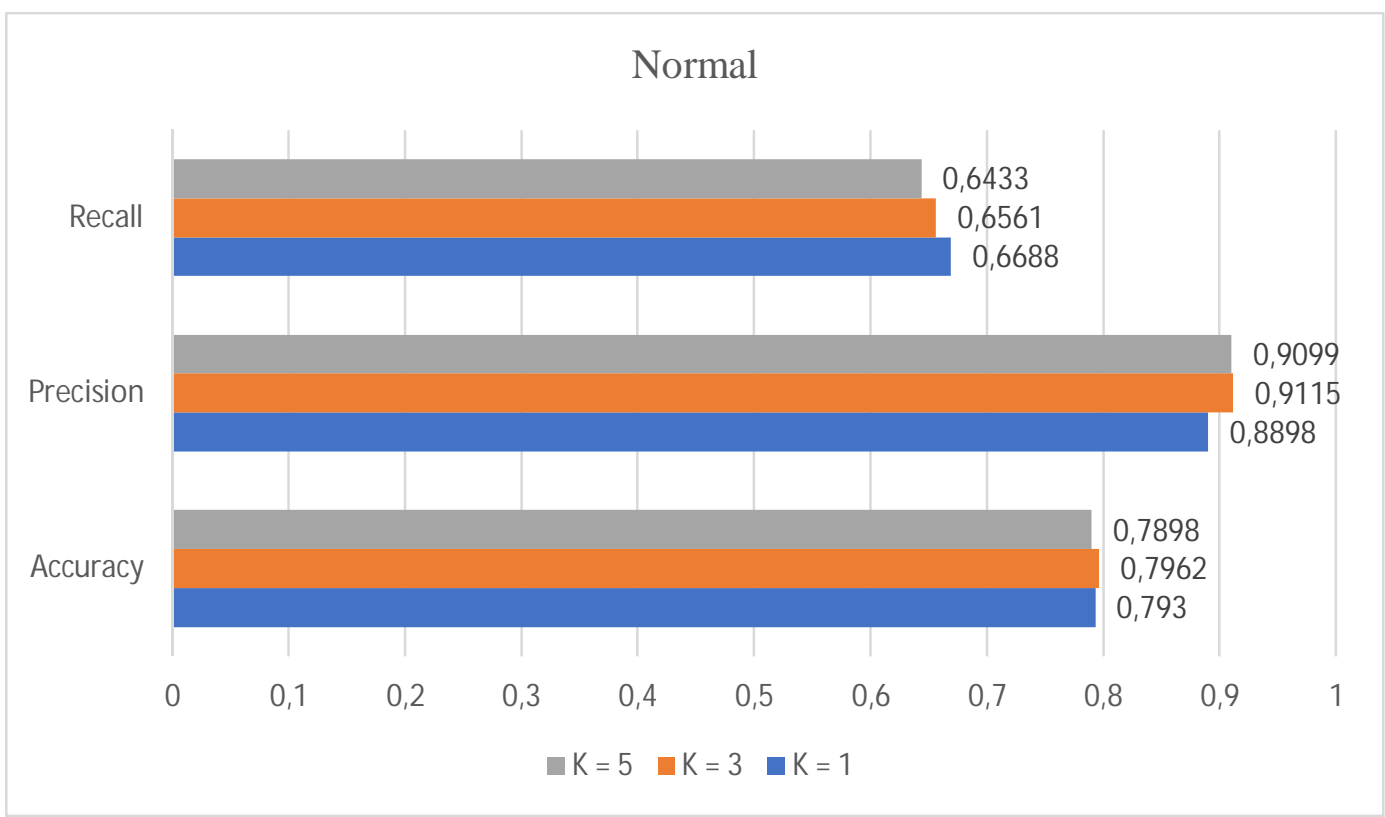

Gambar 5. Grafik Normal berdasarkan $K=1, K=3$, dan $K=5$

Dari Gambar 5 bisa disimpulkan bahwa dari 3 parameter K untuk tingkat akurasi pada kelas normal yang terbesar adalah $K$-Nearest Neighbor dengan parameter $\mathrm{K}=3$, Gabor Filter dengan Parameter 0.5, dan Wiener Filter dengan Parameter 100, 200, dan 300 sebesar 79,62\%, tingkat Presisi sebesar 91,15\%., tingkat recall sebesar 65,61\%. Pada kelas normal terdapat tingkat recall yang agak kurang baik dikarenakan sebagian data yang diprediksi normal terdapat data dengan label pneumonia. Secara keseluruhan model K-Nearest Neighbor $(K-N N)$, Gabor Filter dengan Wiener Filter cukup baik dalam memprediksi penyakit pneumonia.

\section{KESIMPULAN} bahwa:

Berdasarkan hasil pengujian yang telah dilakukan dapat disimpulkan dari penelitian ini

1. Klasifikasi menggunakan KNN dengan ekstraksi fitur Wiener Filter dan Gabor Filter dapat menghasilkan performa cukup baik dalam mengklasifikasi penyakit pneumonia dan non pneumonia pada citra $x$-ray

2. Perfoma $K-N N$ dengan $\mathrm{K}=3$, fitur Gabor Filter dengan frequency $=0.5$ dan Wiener Filter dengan noise $=100,200,300$ mendapatkan nilai akurasi (accuracy) tertinggi sebesar $79,62 \%$, untuk nilai precision sebesar $91,15 \%$, dan untuk nilai recall sebesar $65,61 \%$ untuk kelas paru-paru normal. Sedangkan untuk kelas paru-paru Pneumonia dengan tingkat akurasi sebesar 79,62\%, untuk precision sebesar 73,13\%, dan untuk recall sebesar 93,63\% dengan jumlah 3.140 data yang terbagi menjadi 2 kelas (normal dan pneumonia) dengan rasio pengujian 90:10 untuk data latih dan data uji sehingga total data latih adalah 314.

Antony, et., al (KNN dan Gabor Filter Serta Wiener Filter untuk Mendiagnosis Penyakit Pneumonia Citra X-Ray pada Paru-paru) 


\section{SARAN}

Berdasarkan penelitian yang telah dilakukan adapun saran dari penulis yang dapat dilakukan oleh peneliti selanjutnya diantara sebagai berikut:

1. Menggunakan metode klasifikasi berjenis un-supervised learning.

2. Memperbanyak data latih untuk pengujian agar tingkat akurasi yang didapat semakin akurat.

3. Menganalisa pengaruh ukuran citra pada klasifikasi model.

\section{DAFTAR PUSTAKA}

[1] Damayanti, N. 2017, Klasifikasi Penyakit Paru Dengan Metode Artificial Neural Network (Ann) (Studi Kasus: Rsud Kertosono) [Institut Teknologi Sepuluh Nopember], In Institut Teknologi Sepuluh Nopember Repository. http://repository.its.ac.id/42312/

[2] Eldianto, M. N. D. 2019, Implementasi Deep Learning pada Sistem Klasfikasi Penyakit Paru Berdasarkan Foto Rontgen Munggunakan Metode Convolutional Neural Network $(C N N)$ [Universitas Jember], http://repository.unej.ac.id/handle/123456789/92073

[3] Aulia, I., Chamid, M. S., \& Andari, S. 2017, Pemodelan Pneumonia pada Balita di Surabaya Menggunakan Spatial Autoregressive Models, Jurnal Sains dan Seni ITS, 6(1), 89-93, https://doi.org/10.12962/j23373520.v6i1.22437

[4] Numan, N., Kusumadewi, S., \& Muzayyanah, N. 2020, Sistem Inferensi Fuzzy Untuk Membantu Diagnosis Penyakit Pneumonia Anak, IT Journal Research and Development, 5(1), 53-62, https://doi.org/10.25299/itjrd.2020.vol5(1).5088

[5] Maysanjaya, I. M. D. 2020, Klasifikasi Pneumonia pada Citra X-rays Paru-paru dengan Convolutional Neural Network, Jurnal Nasional Teknik Elektro Dan Teknologi Informasi, 9(2), 190-195, https://doi.org/10.22146/jnteti.v9i2.66

[6] Sapata, B. M., \& Juniati, D. 2019, Klasifikasi Penyakit Paru Berdasarkan Citra X-Ray Thorax Menggunakan Metode Fraktal Box Counting, MATHunesa, 7(3), 228-235. https://jurnalmahasiswa.unesa.ac.id/index.php/mathunesa/article/view/30272

[7] Rahmadewi, R., \& Kurnia, R. 2016, Klasifikasi Penyakit Paru Berdasarkan Citra Rontgen Dengan Metoda Segmentasi Sobel, Jurnal Nasional Teknik Elektro, 5(1), 7. https://doi.org/10.25077/jnte.v5n1.174.2016

[8] Wati, R. A., Irsyad, H., \& Rivan, M. E. Al. 2020, Klasifikasi Pneumonia Menggunakan Metode Support Vector Machine, Jurnal Algoritme, 1(1), 21-32. http://jurnal.mdp.ac.id/index.php/algoritme/article/view/429

[9] Ibrahim, E.-S. H. 2017, Heart Mechanics, https://www.routledge.com/Heart-MechanicsMagnetic-Resonance-ImagingAdvanced-Techniques-

Clinical/Ibrahim/p/book/9780367871185

[10] Khairunnisa, K., Rismayanti, R., \& Alhari, R. 2018, Analisis Identifikasi Wajah Menggunakan Gabor Filter dan Skin Model, Jurnal Teknologi Informasi, 2(2), 150. https://doi.org/10.36294/jurti.v2i2.430 
Jurnal Algoritme

Vol. 1, No. 2, April 2021, Hal. 147-155

[11] Gonzalez, R. C., \& Woods, R. E. 1980, Book Review: Digital Image Processing. In The International Journal of Electrical Engineering \& Education (Vol. 17, Issue 3), https://doi.org/10.1177/002072098001700324

[12] Heryana, N., \& Mayasari, R. 2016, Implementasi Nose Removal Menggunakan Wiener Filter Untuk Perbaikan Implementasi Noise Removal Menggunakan Wiener Filter Untuk Perbaikan Citra Digital, UNSIKA Syntax Jurnal Informatika, 5, 159-164.

[13] Sinaga, R. D. 2017, Perbandingan Metode Wiener Filter dan Trivariate Shrinkage, Konferensi Nasional Teknologi Informasi dan Komputer (KOMIK), I, 291-294.

[14] Suyanto. 2018, Machine Learning Tingkat Dasar dan Lanjut (Suyanto (ed.); 1st ed.), Informatika, Bandung.

[15] Dennes Nur Dwi Iriantoro, Candra Dewi, D. F. 2018, Klasifikasi pada Penyakit Dental Caries Menggunakan Gabungan K-Nearest Neighbor dan Algoritme Genetika, Jurnal Pengembangan Teknologi Informasi Dan Ilmu Komputer, 2(8), 2926-2933.

[16] Silmina, E. P., \& Hardiani, T. 2018, Perancangan Sistem Pakar Penyakit Pneumonia pada Balita Menggunakan Algoritme K-NN (K-Nearest Neighbor), Pseudocode, 5(2), 5663. https://doi.org/10.33369/pseudocode.5.2.56-63

[17] Wijaya, C., Irsyad, H., \& Widhiarso, W. 2020, Klasifikasi Pneumonia Menggunakan Metode K- Nearest Neighbor Dengan Ekstraksi GLCM, Jurnal Algoritme, 1(1), 33-44. http://jurnal.mdp.ac.id/index.php/algoritme/article/view/431 